\title{
Artikel Review : Crowdfunding dan Hubungan Erat nya dengan Digital Humanities
}

\section{Nama : Arvin Winatha}

\section{Email : s130119032@student.ubava.ac.id}

Crowdfunding adalah sejenis crowdsourcing dari orang banyak dengan memungkinkan support secara online untuk terlibat dalam proyek sosial untuk berkontribusi pada sumber daya dalam menangani masalah sosial. Crowdfunding dapat diartikan sebagai cara untuk mengembangkan aktivitas usaha melalui proses penggalangan dana, dimana wirausahawan sosial menyuarakan kampanye mereka dengan lebih baik daripada di platform/media biasa. Proses nya melibatkan sekelompok orang yang mengumpulkan uang melalui internet untuk mendukung proyek tertentu. Kontribusi finansial crowd funding terdiri dari berbagai jenis, antara lain lending, equity, reward dan donasi. (Pratono, et al., 2020)

Digital Humanities dalam aplikasinya mengadopsi Crowdfunding beserta platformnya dalam mendorong perusahaan sosial untuk membentuk kembali misi sosial dengan tindakan yang lebih responsif. Strategi yang dilakukan yaitu bisa melalui Social Networking and Provide Information. Strategi yang dapat dilakukan lagi yaitu perusahaan sosial mempekerjakan pekerja professional dengan pengaturan kerja yang fleksibel untuk menarik investor. Selain itu, adopsi crowdfunding dalam digital humanities ini dapat dilakukan dengan 3 hal yaitu, Investigating the mission drifting, risk sharing/berbagi resiko dari pasar modal ke dalam kelompok tertentu, dan Human resource practices. (Pratono, et al., 2020)

Di kota Berlin, Crowdfunding menjadi metode untuk memobilisasi uang tunai, modal dan antusiasme koletif yang diperlukan untuk kewirausahaan sosial dan pembaruan di kota-kota.. Strategi di kota Berlin yaitu dengan observasi peserta lokakarya keuangan untuk wirausahawan sosial, dan 21 wawancara rahasia tatap muka semi-terstruktur dengan perwakilan dari platform crowdfunding dan lembaga keuangan terkait lainnya. Platform crowdfunding yang digunakan yaitu reward platforms dan StartNext. Tipe crowdfunding yang diterapkan di Berlin ada Reward crowd funding, Real estate crowd funding dan donation crowdfunding. (Langley, Lewis, McFarlane, Painter, \& Vradis, 2020)

Contoh pemecahan masalah menggunakan crowdfunding lainnya terdapat pada aksi Crowdfunding energy terbarukan (RE) yang telah mengalami pertumbuhan kuat di Kota negara Perancis. Crowdfunding Energi terbarukan (ET) mendukung transisi dari fosil ke sumber ET dengan strategi mendiversifikasi pendanaan secara bersamaan, mengikat investor ritel ke transisi energy, dan mendorong penerimaan lokal serta menggunakan sarana platform online. Data RE crowdfunding dikumpulkan melalui survei terhadap 8 perusahaan. (Bourcet \& Bovari, 2020)

Dari ke 3 sumber di atas, masing-masing memiliki strategi dalam mengadopsi crowdfunding dalam digital humanities. Artikel (Pratono, et al., 2020) yang menggunakan Social Networking dan provide information. Artikel Crowdfunding di Kota Berlin dan daerah di Perancis cenderung menggunakan online platform dalam mengumpulkan sumber pembiayaan. 


\section{Bibliography}

Bourcet, C., \& Bovari, E. (2020). Exploring citizens' decision to crowdfund renewable energy projects: Quantitative evidence from France. Energy Economics, 88. doi:https://doi.org/10.1016/j.eneco.2020.104754

Langley, P., Lewis, S., McFarlane, C., Painter, J., \& Vradis, A. (2020). Crowdfunding cities: Social entrepreneurship, speculation and solidarity in Berlin. Geoforum, 115, 11-20. doi:https://doi.org/10.1016/j.geoforum.2020.06.014

Pratono, A. H., Prima , D. A., Sinaga, F. N., Permatasari, A., Ariani, M., \& Han, L. (2020). Crowdfunding in digital humanities : some evidence from Indonesian social enterprises. Aslib Journal of Information Management, 72(2), 287-303. 